\title{
Claiming a refund of subsidies for non-public educational units - selected legal problems
}

\section{Dochodzenie zwrotu dotacji dla niepublicznych jednostek oświatowych - wybrane problemy prawne}

\begin{abstract}
The purpose of the article is to analyse selected substantive and procedural legal issues, which relate to claiming a refund of subsidies for non-public educational units. The author argues that the legally defined rules for granting and spending educational subsidies are not sufficiently clear and precise. Furthermore, variable and inconsistent judgements of administrative courts do not help in their interpretation. In discussing selected problems, the author puts forward de lege ferenda postulates aimed at resolving the identified concerns.
\end{abstract}

Keywords: educational subsidies; refund of subsidies.

Streszczenie. Przedmiotem artykułu jest analiza wybranych w oparciu o praktykę organów administracji problemów z zakresu prawa materialnego i procesowego, które wiążą się z tematyką dochodzenia zwrotu dotacji dla niepublicznych jedno- 
stek oświatowych. Autor stawia tezę, że określone prawnie zasady przyznawania i wydatkowania dotacji oświatowych nie są w wystarczającym stopniu jasne i precyzyjne, a w ich wykładni nie pomaga chwiejne i niejednolite orzecznictwo sądów administracyjnych. Omawiając wybrane zagadnienia, autor zgłasza postulaty de lege ferenda, zmierzające do usunięcie dostrzeżonych wątpliwości.

Słowa kluczowe: dotacje oświatowe; zwrot dotacji.

\section{Introduction}

Until 31 December 2017, non-public kindergartens, other forms of a pre-school education, schools, and institutions received subsidies from budgets of relevant local government units pursuant to the provisions of the School Education Act of 7 September 1991 ${ }^{1}$. Since 1 January 2018, these entities have been receiving public support according to rules set out in the Act of 27 October 2017 on Financing Educational Tasks ${ }^{2}$.

The educational subsidy is of an annual nature, and results, not only from the provisions of AFET (Article 34(1), and Article 35(3), but also from the provisions of the Public Finance Act of 27 August 2009 3 . It should be remembered that it is granted from the budget of a local government unit, which is an annual financial plan adopted for the financial year, which is the calendar year (Article 211(1-3) of the PFA), while the list of planned amounts of subsidies consists of an attachment to the budget resolution (Article 214(1) of the PFA). At the same time, in the literature on the subject and case law of administrative courts, an educational subsidy is qualified either as an earmarked and designated subsidy (of a mixed nature) $)^{4}$, or only as an earmarked subsidy ${ }^{5}$.

1 Consolidated text: Dz.U. [Polish Journal of Laws] of 2017, poz. [item] 2198 with subsequent amendments, hereinafter: SEA.

Dz.U., poz. 2203 with subsequent amendments, hereinafter: AFET.

Consolidated text: Dz.U. of 2019, poz. 869 with subsequent amendments, hereinafter: PFA.

4 Cf. J. Kokot, Commentary on Art. 90 of SEA [in:] A. Balicki, M. Pyter, J. Kokot (ed.), Ustawa o systemie oświaty. Commentary (ed. I, Legalis 2016); a judgment of the Supreme Administrative Court of 17 November 2016, II GSK 1194/15, Central Database of Administrative Court Decisions (CBOSA); a judgment of the Voivodeship Administrative Court in Bydgoszcz of 4 October 2016, I SA/Bd 412/16, CBOSA. 
On the basis of both old (SEA) and new (AFET) regulations, no situation is indicated in which an obligation to refund educational subsidies arises. Thus, the regulations of PFA apply in this case, in the light of which the amounts of subsidies to be refunded as revenues of the budget of a local government unit constitute non-tax budgetary receivables of a public and legal nature (Article 60 of the PFA). Consequently, the refund obligation applies to educational subsidies: 1) unused by the end of the financial year (Article 251(1) of the PFA); 2) misused (Article 252(1)(2) of the PFA); 3) unduly received, i.e. without a legal basis (Article 252(1)(2) of the PFA); 4) received in excess (Article 252(1)(2) of the PFA).

The purpose of this work is to discuss issues in substantive and procedural law selected on the basis of the practice of administrative bodies conducting proceedings to determine the amount of educational subsidies to be refunded. The subjects of consideration will be, in turn: an analysis of the legitimacy of recognising unsettled funds paid to bodies governing nonpublic educational units under the judgments of common courts as subsidies unused on time; an assessment of the admissibility of spending educational subsidies to finance the tasks of the governing body before 31 March 2015; establishing rules for the limitation period of the obligation to refund a misused educational subsidy; an attempt to clarify the legal consequences arising from the statutory setting of deduction limits in the event of an overpayment of a subsidy arising from an update of the amount of the subsidy during the financial year; and procedural problems seen in the context of proceedings to determine the amounts of subsidies to be refunded.

5 Cf. J. Pierzchała, Prawo oświaty prywatnej, Warszawa 2016, p. 154; M. Pilich, Commentary to Art. 90 of SEA [in:] M. Pilich (ed.), Ustawa o systemie oświaty. Commentary (Ed. VI, LEX 2015); P. Świątek, Wykorzystanie dotacji udzielonych z budżetu jednostek samorzq̨du terytorialnego dla niepublicznych jednostek systemu oświaty w świetle orzecznictwa sq̨ów administracyjnych „Finanse Komunalne” 2017, No 7-8, p. 50; M. Szalewska, Zwrot dotacji przez przedszkola niepubliczne [in:] A. Borodo (ed.), Dotacje i subwencje w systemie finansowym samorzqdu terytorialnego, Toruń 2013, p. 240; A. Pawlikowska, W. Lachiewicz, Dochodzenie zwrotu dotacji przez beneficjenta [in:] W. Lachiewicz, A. Pawlikowska (ed.) Dotacje oświatowe, Warszawa 2019, p. 242; judgment of the Supreme Administrative Court of 12 December 2013, II GSK 1482/12, CBOSA; judgment of the Supreme Administrative Court of 25 April 2017, II GSK 1916/15, CBOSA. 


\section{Lack of settlement of funds paid as a result of a common court judgment as a manifestation of a failure to use the subsidy on time}

For many years, an act of granting (establishing and transferring) an educational subsidy was classified in a doctrine and case law in two manners. Indicating only the essence of the dispute, it should be mentioned that, according to the first position, it was only a technical activity of bookkeeping and accounting nature falling under civil law relationship established between the granting authority and its beneficiary ${ }^{6}$. On the other hand, according to the second view, it was a public administration activity that was not a decision regarding rights or obligations arising from legal provisions ${ }^{7}$. After 2007, a "pro-civilian” case-law had been dominating, and administrative courts usually declared themselves to lack subjectmatter jurisdiction to adjudicate on subsidy payments ${ }^{8}$.

Since 1 January 2017, it has been possible to find paragraph 11 in Article 90 of the SEA, according to which the grant of an educational subsidy constituted an activity in the field of public administration referred to in Article $3 \S 2$ point 4 of the Act of 30 August 2002 - Law on Proceed-

6 This case law was initiated by the Supreme Court judgment of 3 January 2007, IV CSK 213/06, LEX No 277297. It was accepted in some decisions of administrative courts - cf. e.g. the decision of the Supreme Administrative Court of 26 January 2011, II GSK 98/10, CBOSA.

7 Cf. a judgment of the Supreme Administrative Court of 17 January 2008, II GSK 320/07, CBOSA; cf. S. Gajewski, Sq̨owoadministracyjna kontrola udzielania dotacji z budżetów jednostek samorzq̨du terytorialnego, o których mowa w art. 90 ustawy z 7.09.1991 r. o systemie oświaty „Finanse Komunalne” 2015, No 4, p. 55.

8 Cf. A. Ostrowska, Spór o właściwość sq̨dowq w sprawach ustalania wysokości dotacji oświatowych „Finanse Komunalne” 2015, No 3, pp. 6 and 8-9. More on the topic, cf. A. Pawlikowska, W. Lachiewicz, Dochodzenie wypłaty dotacji w należnej kwocie tryb dochodzenia [in:] W. Lachiewicz, A. Pawlikowska (ed.), Dotacje oświatowe..., pp. 215-218. The issue of a claim for a budget subsidy and the procedure in which the subsidy case will be examined in relation to various legal forms of subsidy, cf. K. Czarnecki, Dotacje budżetowe. Konstrukcja prawna i procedury, Toruń 2018, pp. 76-79. 
ings before Administrative Courts ${ }^{9}$. This provision was applicable starting from the subsidies for $2017^{10}$. Currently Article 47 of the AFET provides that activities undertaken by the subsidising body referred to in Article 1521, and Article 25, Article 26, Article 28-32, and Article 40-41a of the AFET, in order to determine the amount or transfer the subsidy referred to in Article 15-21, and Article 25, Article 26, Article 28-32, and Article 4041a of the AFET, constitute public administration activities referred to in Article $3 \S 2$ point 4 of the LPAC. The indicated regulations clearly determine that, starting from the subsidies for 2017, the bodies governing non-public educational units cannot seek the determination and the payment of the subsidy due in civil proceedings ${ }^{11}$. This situation is not favourable to those bodies because it deprives them of the possibility of obtaining a judgment in which the court would set the amount of the subsidy due to be paid with all further consequences, including the possibility of executing such a judgment by means of enforcement.

The effect of the unclear legal status from before 2017 is, however, that non-public educational units have received, are receiving, and may still receive, funds from local government units granted in the form of court judgments on account of due, but unpaid subsidies. The legal classification of these measures raises significant doubts. Common courts, while ruling on this matter, will consider them to have a nature of damages ${ }^{12}$.

9 Dz.U. [Journal of Laws] of 2018, poz. [item] 1302 with subsequent amendments, hereinafter: LPAC. With regard to the amendment to Article 90 of the SEA; see Article 1 point 78 letter. $x$ of Act of 23 June 2016 amending the Act on the Education System and some other acts (Dz.U., poz. 1010 with subsequent amendments).

10 See Article 27(1) of the Act of 23 June 2016 amending the Act on the Education System and some other acts.

11 Similarly, cf. A. Olszewski, Konsekwencje intertemporalne zmiany przepisów regulujących kwestie dotowania przedszkoli, szkół oraz placówek prowadzonych przez podmioty inne niż jednostka samorzq̨du terytorialnego $w$ zakresie dopuszczalności drogi sqdowej „Finanse Komunalne” 2018, No 4, p. 9. Such a position was adopted by the Supreme Court in its decision of 3 July 2019, II CSK 425/18, LEX No 2690996. See also M. Domagalski, Gdzie iść ze sporem o dotacje oświatowe „Rzeczpospolita” of 4 July 2019, No 11397, p. A14.

12 Cf. a judgment of the Supreme Court of 27 March 2019, V CSK 101/18, LEX No 2652272. Similarly, cf. M. Pilich, Commentary on Article 90 of the SEA [in:] M. Pilich (ed.) Ustawa o systemie oświaty. Komentarz, Warszawa 2012, VI, Legal Information System LEX 2015. 
Administrative courts also note that in such cases we are no longer dealing with a "pure" subsidy, but with the payment of a claim that was not granted (awarded) and consequently paid ${ }^{13}$.

The practice of administrative bodies shows that in the event of a lack of settlement of funds paid pursuant to judgments of common courts, proceedings are instituted regarding the determination of the amount of the subsidy to be refunded to the budget of the relevant local government unit as unused on time. Pursuant to Article 251(1) of the PFA subsidies granted from the budget of the local government unit in the unused part until the end of the financial year shall be refunded to the budget of that unit by 31 January of the following year. It should be assumed that an unused subsidy is one that has not been spent on payment for completed tasks or has not been used to achieve the objectives indicated in separate provisions (a contrario to Article 251(4) of the PFA). At the same time, administration bodies accept one of two options - they require settlement of the funds paid out with expenses from the year to which the subsidy relates to, or with expenses from the year in which the payment was made.

The demand for fund settlement with expenses from the year in which they were paid as a result of a court judgment does not deserve approval. The principles of elementary logic contradict such a demand. Since the subsidy was not granted in the year in which it should have been granted, despite the implementation of public tasks, it (the subsidy) could not have been used and consequently settled for the year for which it was due. After all, in the year for which the subsidy was due, the body governing a private kindergarten, school, or other institution financed the educational tasks with the funds at its disposal ${ }^{14}$.

The analysis of the second possible solution raises more doubts, i.e. a demand for fund settlement with expenses from the year in which the funds were paid. However, it is also difficult to accept such a solution.

13 Cf. a judgment of the Voivodeship Administrative Court in Białystok of 16 April 2014, I SA/Bk 110/14, CBOSA.

14 Similarly, cf. ibid. Resolution of the College of the Regional Accounting Chamber in Poznań of 21 February 2018, 6/317/2018, LEX No 2460347. 
First, the educational subsidy is annual, and its amount in a given year for a particular institution depends on the number of students attending this institution in that year. It should be emphasised here that, although the beneficiaries of the subsidy are formally non-public educational units, the actual beneficiaries are to be the students themselves. Thus, the amount of funds paid under ordinary court judgments is determined based on the number of students attending the institution in the year for which the subsidy was due, and not in the year in which the relevant amount was adjudged or paid (the number of students was probably different at that time). Secondly, you cannot request a settlement of the subsidy due for a given accounting period with expenses from another accounting peri$\mathrm{od}^{15}$. Thirdly and probably most importantly, neither of the SEA regulations, which are no longer in force, and the existing regulations of the AFET provides for legal mechanisms regarding the settlement of funds received by non-public units of the education system on the basis of judgments of common courts as a result of an action for payment of the unpaid subsidy or its part ${ }^{16}$. In my opinion, such a legal basis cannot be constituted by acts of local law in the form of resolutions of legislative bodies of local government units regarding the grant and the settlement of subsidies and the procedure for controlling the accuracy of their collection and use currently issued pursuant to Article 38(1) of the AFET (previously based on Article 90(4) of the SEA), as, this provision refers to determining the procedure of settlement of "subsidies", and it is difficult to assign such a character to the measures concerned. Of course, it does not change the fact that in legal transactions one may find resolutions of legislative bodies of local government units containing such regulations whose legality has not been effectively questioned. Administrative courts, adju-

15 Cf. A. Pawlikowska, W. Lachiewicz, Uchwała dotyczq̨ca udzielania i rozliczania dotacji oświatowych oraz kontroli prawidłowości ich pobierania i wykorzystania [in:] W. Lachiewicz, A. Pawlikowska (ed.), Dotacje oświatowe..., p. 158.

16 Cf. the reply of the Under-secretary of State in the Ministry of National Education Joanna Berdzik - under the authority of the minister - of 11 June 2014 to the parliamentary interpellation No 26009 regarding the nature of the funds received by nonpublic kindergartens in connection with final decisions of the determining bodies, Sejm of the 7th term, http://www.sejm.gov.pl/sejm7.nsf/InterpelacjaTresc.xsp?key=3C942F13, (access on-line: 13.09.2019). 
dicating in matters of complaints about decisions in which amounts of subsidies to be refunded as unused on time were determined for the bodies governing non-public units of the education system - with reference to the resolutions of the legislative bodies of local government units determining the obligation to settle the funds paid under the judgments of common courts - are entitled to refuse to apply such regulations of local law acts pursuant to Article 178(1) of the Constitution of the Republic of Poland of 2 April 1997 (hereinafter referred to as: the Constitution) ${ }^{17}$, and Article 4 of the Act of 25 July 2002 Law on the System of Administrative Courts ${ }^{18}$.

To sum up, de lege lata administrative bodies cannot consider the unsettled funds paid on the basis of judgments of common courts as subsidies unused on time within the meaning of Article 251(1) of the PFA. Moreover, analogous remarks can be made regarding the control of the proper use of these funds, pursuant to Article 252(1) point 1 of the PFA, for which no legal grounds currently exist. Such actions will become possible only as a result of relevant legislative actions attributable to the legislator. They are desirable, because the unclear legal nature of funds paid under common court judgments cannot be separated from the public (educational) purpose of both the funds transferred and the activities of non-public educational units themselves.

\section{Admissibility of financing expenses related to the implementation of the tasks of the governing body with funds from educational subsidies}

Pursuant to Article 252(1) point 1 of the PFA, subsidies granted from the budget of a local government unit used contrary to its purpose shall be

\footnotetext{
Dz.U. No 78, poz. 483 with subsequent amendments.

18 Consolidated text: Dz.U. of 2018, poz. 2107 with subsequent amendments. On the admissibility of assessing the constitutionality and legality of the provisions of primary rank by the court hearing the individual case, in general see a judgment of the Supreme Administrative Court of 24 October 2018, II FSK 1098/18, CBOSA and the decisions indicated therein.
} 
refunded to the budget together with interest in the amount specified as for tax arrears within 15 days from the day on which the circumstances referred to in the said provision are ascertained. Bearing in mind the aforementioned Article 251(4) of the PFA, it should be assumed that the use of an educational subsidy contrary to its intended use will occur when the beneficiary has spent the funds transferred to him in whole or in part on the implementation of tasks other than those specified for this type of subsidy in the provisions of generally applicable law.

Importantly, the content of Article 252(1) point 1 of the PFA shows that the obligation to refund a misused subsidy arises by virtue of law

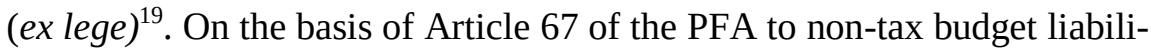
ties of a public nature (including educational subsidies), the provisions of Section III of the Act of 29 August 1997 - Tax Ordinance ${ }^{20}$ shall apply accordingly. Considering the two ways of creating tax liabilities consistent with this Act, it must be clearly stated that the obligation in the form of a refund of a misused educational subsidy arises on the day of the occurrence of the event with which the Act binds the creation of such liability (Article $21 \S 1$ point 1 of the TO). The decision in which the administrative body determines for the body governing the non-public unit of the education system the amount of the subsidy to be refunded to the budget of the relevant local government unit as misused, will therefore be a declaratory decision, in essence similar to the decision referred to in Article $21 \S 4$ in connection with Article $21 \S 3$ of the $\mathrm{TO}^{21}$. The consequence of this state of affairs is the obligation to apply the so-called old provisions to assess the compliance of the use of educational subsidies with the law, i.e. the provisions in force at the time when individual expenses were incurred $^{22}$. This is especially important if we consider that the extent of

19 Cf. M. Stawiński, Commentary on Article 252 of the PFA [in:] Z. Ofiarski (ed.), Ustawa o finansach publicznych. Komentarz, Legal Information System LEX 2019.

20 Consolidated text: Dz.U. of 2019, poz. 900 with subsequent amendments, hereinafter: TO.

21 Cf. a judgment of the Voivodeship Administrative Court in Warsaw of 4 December 2013, V SA/Wa 1336/13, CBOSA; a judgment of the Voivodeship Administrative Court in Gliwice of 26 August 2015, I SA/Gl 49/15, CBOSA.

22 Cf. a judgment of the Supreme Administrative Court in Wrocław of 28 September 1999, I SA/Wr 926/98, CBOSA. 
permissible expenses that can be covered by educational subsidies has changed over the years.

The above observations are necessary in order to understand the issue in the judicial practice of administrative bodies, which is the admissibility of allocating funds from educational subsidies for the implementation of the tasks of the body governing a private kindergarten, a school, or other institution. In the light of the current legislation, the situation is clear. In Article 35(1)(1)(b) of the AFET it was found that educational subsidies may be used to finance expenses related to the implementation of the tasks of the governing body referred to in Article 10(1) of the Act of 14 December 2016 - Educational $\mathrm{Law}^{23}$. In the past, however, the situation in this area was much less clear.

The scope of tasks that may be financed from funds from an educational subsidy was specified for the first time in par. 3d added to Article 90 of the SEA by means of an amendment to this Act, which entered into force on 22 April $2009^{24}$. At the time, this provision provided that subsidies concerned could be used to finance the implementation of the

23 Consolidated text: Dz.U. of 2019, poz. 1148 with subsequent amendments, hereinafter: EL. This provision states that the body governing the school or institution is responsible for its activities. The tasks of the body governing the school or institution include in particular: 1) ensuring the operating conditions of the school or institution, including safe and hygienic conditions for studying, upbringing, and care; 2) ensuring conditions enabling the use of a special organization of learning and working methods for children and adolescents covered by special education; 3) renovation of school facilities and investment tasks in this area; 4) providing administrative services, including legal services, financial services, including in the scope of performing the activities referred to in Article 4(3) points 2-6 of the Accounting Act of 29 September 1994 (Dz.U. of 2019, poz. 351), and organizational support for the school or institution; 5) equipping the school or institution with teaching aids and equipment necessary for the full implementation of curricula, educational, and preventive programmes, conducting examinations and performing other statutory tasks; 6) performing activities in matters of labour law in relation to the headmaster of a school or institution; 7) transfer to schools for children and adolescents and institutions referred to in Article 2 point 7, with the exception of art schools providing only artistic education, information on entities performing medical activity providing health services in the field of dental treatment for children and adolescents financed from public funds.

24 See Article 1 point 38 letter e of the Act of 19 March 2009 amending the Act on the Education System and amending certain other acts (Dz.U. No 56, poz. 458 with subsequent amendments). 
school's or institution's tasks in the field of education, upbringing and care, including social prevention. Subsidies could only be used to cover the current expenses of the school or institution. Since 1 January 2014, Article 90(3d) was in force in the new, extended version ${ }^{25}$. At that time, the concept of "current expenses" of schools, kindergartens, and other forms of pre-school education and facilities was clarified, and it was added that the mentioned public funds may be allocated to the purchase of tangible assets, and intangible and legal assets listed in this provision. However, nothing was mentioned about the possibility of financing expenses related to the implementation of the tasks of the governing body from the educational subsidy. Such an opportunity was explicitly allowed only by way of another amendment to Article 90(3d) of the SEA, which entered into force on March 31, 2015 - referring to the catalogue of tasks of the governing body from Article 5(7) of the SEA (Article 90 (3d)(1)(b) of the SEA $)^{26}$ which was applicable at that time.

It might seem that the history of the legislative changes described in Article 90(3d) of the SEA makes it possible to state without major difficulties that the spending of educational subsidies on the implementation of the tasks of a body governing a private education unit has become possible only since 31 March 2015, the more so since the legal solutions described were not given retroactive effect in any respect. Such a reasonable point of view was initially congruently presented in the case law of administrative courts, where it was emphasized that the purpose of an educational subsidy is not to finance the implementation of the tasks of a body governing an educational institution, because according to the SEA regulations, the final beneficiary of the subsidy is to be the student towards whom the institution performs the functions of education, upbringing, and care, including social prevention ${ }^{27}$. It was sometimes added correctly that

25 See Article 1 point 20 letter e of the Act of 13 June 2013 amending the Act on the Education System and certain other acts (Dz.U. poz. 827 with subsequent amendments).

26 See Article 1 point 61 letter b of the Act of 20 February 2015 amending the Act on Education System and certain other acts (Dz.U. poz. 357 with subsequent amendments).

27 See e.g. a judgment of the Supreme Administrative Court of 19 March 2014, II GSK 1858/12, CBOSA; a judgment of the Supreme Administrative Court of 14 May 2014, II GSK 229/13, CBOSA; a judgment of the Supreme Administrative Court of August 
the direction of legislative changes and historical interpretation speak for the correctness of such a position ${ }^{28}$.

Sources of controversy in the present subject matter should be seen in the explanatory statement of the draft law of 20 January 2015, amending the act on the education system and certain other acts. The authors of the project noted there that the proposed change in the wording of Article $90(3 d)$ is more precise,

“[...] confirming (in line with the existing practice in the interpretation of this provision) that as part of current expenses of schools, kindergartens, other forms of pre-school education, and facilities that can be covered by subsidies, expenses related to the implementation of the tasks of the leading body may also be taken into account, which are referred to in Art. 5(7) of the School Education Act." ${ }^{29}$.

Over time, the view that it was legal to allocate funds from the educational subsidy to expenses related to the implementation of the tasks of the governing body also before 31 March 2015 was adopted, not only in the literature, but also in the case law of administrative courts, including the Supreme Administrative Court. In its support, it was argued that in the

26, 2014, II GSK 1002/13, CBOSA; a judgment of the Voivodeship Administrative Court in Warsaw of 30 January 2015, III SA/Wr 717/14; a judgment of the Voivodeship Administrative Court in Bydgoszcz of 4 October 2016, I SA/Bd 412/16. In this context, it is misleading to say that, in essence, the beneficiary of the subsidy was the governing body and not the school it governs. Cf. A. Szymańska, M. PodleśnaPorczak, K. Kułakowska Udzielanie dotacji z budżetów jednostek samorzq̨du terytorialnego jednostkom oświatowym - dylematy prawne w świetle ustaleń kontroli regionalnych izb obrachunkowych „Finanse Komunalne” 2014, No 10, p. 50.

28 See the judgment of the Voivodeship Administrative Court in Bydgoszcz of 23 August 2016, I SA/Bd 304/16, CBOSA.

29 Government draft law amending the Act on the Education System and some other acts, Sejm print No 2957, Sejm of the 7th term, http://orka.sejm.gov.pl/Druki7ka.nsf/0/00C53BA3AE174921C1257DA2004A5E82/\% 24File/2957.pdf, (access on-line: 16.09.2019). 
explanatory statement of the draft law a specific "authentic interpretation" was made of the provision before the change ${ }^{30}$.

In my opinion, the rules of logic and the timeless rules for the interpretation of legal texts must lead to a criticism of the ultimately formed case law of the administrative courts. Conclusions resulting from the amendment to Article 90(3d) of the SEA, which entered into force on 31 March 2015, should be completely different from those finally adopted. Since the "rational legislator" decided to interfere in the content of Article 90(3d) of the SEA by explicite entering into it that subsidies may also be used to finance expenses related to the implementation of the tasks of the governing body, which was then provided by Article 5(7) of the SEA, it means that before 31 March 2015 this method of allocating funds from the subsidy was not legally permissible. Rightly on the basis of another case, the Supreme Administrative Court noted that it is unacceptable to assume that an amendment to a given provision determines that it had implicitly the same meaning before the amendment ${ }^{31}$. Based on a logic similar to that finally adopted, it could be considered, for example, that amending the Act of 6 June 1997 - the Penal Code ${ }^{32}$ by introducing a new type of a prohibited act means that this act was also punishable before an entry into force of the amendment, and the relevant amendment was only to confirm this status.

Polish legal system is not familiar with an institution of a so-called official authentic interpretation of legal acts, i.e. having the binding force

30 Cf. M. Pilich, Commentary on Article 90 of the SEA [in:] M. Pilich (ed.), Ustawa o systemie oświaty. Komentarz, Warszawa 2012, VI, Legal Information System LEX 2015; cf. a judgment of the Supreme Administrative Court of 26 February 2016, II GSK 2197/14, CBOSA; a judgment of the Supreme Administrative Court of 19 January 2017, II GSK 1355/15, CBOSA; a judgment of the Supreme Administrative Court of 23 May 2017, II GSK 2647/15, CBOSA; a judgment of the Voivodeship Administrative Court in Bydgoszcz of 29 August 2017, I SA / Bd 714/17, CBOSA.

31 Cf. the Supreme Administrative Court of 5 January 2016, I OSK 1693/15, CBOSA. The case boiled down to the correct interpretation of Article 12b(5) of the Act of 17 May 1989 Geodetic and Cartographic Law (consolidated text: Dz.U. of 2019, poz. 725 with subsequent amendments) in the version of this provision in force before the amendment made by the Act of 15 May 2015 amending the Act Geodetic and Cartographic Law (Dz.U., poz. 831).

32 Consolidated text: Dz.U. of 2018, poz. 1600 with subsequent amendments. 
of interpretation made by the entity that has established a given norm. This is because someone establishes the law under the conditions of a principle of separation of powers from Article 10 of the Constitution and someone else applies it. Of course, the views of the entity that set the legal norm are relevant in the process of its interpretation. The problem, however, is that such observations cannot lead to contra legem ${ }^{33}$ consequences. As the Supreme Court rightly noted in one of its decisions, the statements contained in the legislative materials undoubtedly illustrate the legislative intentions of the legislator and may be helpful in explaining the meaning of the norms examined. Nevertheless, they are not the final and decisive argument. At the moment of the adoption of the law and its entry into force, its text is of the utmost importance ${ }^{34}$. In the present case, the results of the language interpretation of Article 90(3d) of the SEA in the version applicable before 31 March 2015 leads to conclusions that are fully acceptable, so there are no grounds to refer to a systemic or teleological interpretation in this respect ${ }^{35}$.

All comments made here are important because, although they relate to the old legal status, administrative and administrative court proceedings are still pending based on it, the essence of which is to assess the use of educational subsidies as intended, also in relation to expenses allotted to finance tasks of the body governing a non-public educational unit.

\section{The limitation period of the obligation to refund a misused educational subsidy}

The content of the above mentioned Article 67 of the PFA determines that in the case of the limitation period of the obligation to refund the misused subsidy, the provisions of Chapter 8 of Section III of the TO will apply. A similar situation will be in other cases where an obligation to refund a subsidy to the budget of the relevant local government unit arises.

33 Cf. L. Morawski, Zasady wykładni prawa, Toruń 2010, p. 36.

34 Cf. a decision of the Supreme Court of 8 November 2006, II KK 83/2006, „Orzecznictwo Sądu Najwyższego w Sprawach Karnych” 2006, item 2114.

35 Cf. L. Morawski, Zasady..., pp. 74 and 196. 
Pursuant to the TO provisions, the method of calculating the limitation period depends on the manner in which a tax liability arises, which may arise as a result of an event with which the tax act links such a liability (Article $21 \S 1$ point 1 of the TO), or as a result of the decision being serviced by the tax authority, determining the amount of the tax liability (Article $21 \S 1$ point 2 of the TO). In the previous part of this article it has already been explained that the obligation to refund the misused subsidy arises by law, and the decision issued in this regard is declaratory. Therefore, in calculating the limitation period, Article $70 \S 1$ of the TO, according to which the tax liability expires after 5 years from the end of the year in which the tax payment deadline lapsed should be applied in this case. The limitation period begins to run regardless of the decision on stating the obligation to refund and only before its expiry, is legally effective service of the governing body possible. The heart of the problem, however, comes down to the answer to the question of from which moment the limitation period should be counted. A comparison of the content of Article $70 \S 1$ of the TO and Article 252(1)(1) of the PFA does not give an unambiguous answer to this question. In the case law of administrative courts it is possible to distinguish several positions on the commencement of the limitation period for the obligation to refund a misused educational subsidy.

The first view focuses on the interpretation of Article 252(1)(1) of the PFA in its part in which it was indicated that the refund of the misused subsidy should take place "within 15 days from the day on which the circumstances referred to in point 1 or point 2 were stated." Consequently, in order for the limitation period to begin, the fact that the subsidy was used contrary to its purpose must first be "determined", and the moment indicating the commencement of the limitation period will be the last day of the 15-day period from the day of "the determination" of the misuse. The manner in which "the determination" may occur is treated quite liberally. It does not have to be only the service of the determining decision to the governing body, but such a function was also attributed to the service of the result of the fiscal control conducted by the no longer existing Treasury Control Office pursuant to Article 27(2) of the Act of 28 September 
1991 on Tax Audit ${ }^{36}$, which is no longer in force. Such a position seems incompatible with the fact that the obligation to refund a misused educational subsidy arises by law. Moreover, it is contrary to the principle of legal security, which in turn results from the constitutional principle of a democratic state of law (Article 2). As the Constitutional Court rightly pointed out in one of its decisions, it is from Article 2 of the Constitution that the legislator's obligation results to shape legal regulations that will support the extinction of uncertainty over times ${ }^{37}$. The manner of the interpretation indicated above does not correlate with this function of the limitation period institution, making the commencement of the limitation period conditional only on a future and uncertain event, which is the statement of the fact that the subsidy was used improperly. This would lead to a situation in which the limitation period institution, which is supposed to act for the benefit of the body governing a non-public educational unit (a debtor), would apply from the date on which takes place a specific action of the body authorized to determine the amount of the subsidy to be refunded to the budget of the relevant local government unit as misused (a creditor).

The allegations raised above underlie another position which is represented in the case law of administrative courts. According to it, the limitation period for the obligation to refund a subsidy which has been misused begins to run at the end of the calendar year in which the period provided for in Article 252(1)(1) of the PFA lapses, on condition, however, that the fact of using the subsidy contrary to its intended use will be determined within 3 years from the end of the calendar year in which the subsidy was collected ${ }^{38}$. This view does not deserve the approval because

36 Text consolidated: Dz.U. of 2016, poz. 720 with subsequent amendments. Such a view, see a verdict of the Supreme Administrative Court of 17 April 2018, I GSK 351/18, CBOSA; cf. a judgment of the Voivodeship Administrative Court in Gliwice of 21 February 2017, I SA / Gl 1038/16, CBOSA.

37 Cf. the judgment of the Constitutional Court of 19 June 2012, P 41/10, OTK-A ZU 2012, No 6, item 65.

38 Cf. a judgment of the Voivodeship Administrative Court in Poznań of 11 January 2017, I SA/Po 890/16, CBOSA. Although in the judgment the problem of the limitation period of the obligation to refund an unduly paid educational subsidy was analysed, it is also a situation covered by the instruction of Article 252(1) of the PFA. 
it is based on the correct application of Article $68 \S 1$ of the TO, which provides that the tax liability arising on the date of service of the tax authority decision, determining the amount of this liability, does not arise if the decision establishing this liability was served after 3 years from the end of the calendar year in which the tax obligation arose. It has already been explained in this article that the obligation to refund the misused educational subsidy is created ex lege, in the manner set out in Article 21 $\S 1$ point 1 of the TO. Therefore, Article 68 of the TO cannot be applied in case of such liabilities.

In the next group of decisions, the beginning of the limitation period is related to the subsidy settlement date. By way of illustration, if the settlement of the subsidy for 2012 in a given local government unit should take place by 31 January 2013, the limitation period for the obligation to refund the subsidy for 2012 used improperly will be at the end of 2018 (the beginning of the period starts from the end of the year in which the subsidy was to be settled) ${ }^{39}$. It is worth mentioning here that the deadline for the settlement of an educational subsidy is not derived from the provisions of the AFET (formerly SEA), nor, the more so, of the PFA. Article 251(1) of the latter act, and despite mentioning the need to refund to the budget of the relevant local government unit a subsidy in the unused part by the end of the financial year by 31 January of the following year, there are no grounds to apply this provision by analogy to a misused subsidy. Pursuant to Article 38(1) of the AFET (formerly Article 90(4) of the SEA) the procedure for settling subsidies is determined by a way of a resolution of the legislative body of local government units. At the same time, the legislator did not introduce any guidelines or restrictions on the dates and rules of settlement. In this situation, taking in to account that although the educational subsidy is annual, it is paid in 12 parts (Article 34(1) of the AFET), we can imagine the adoption of legal solutions at the local level that differ significantly from each other, such as semi-annual and annual settlements. As a result, the beginning of the limitation period for the obligation to refund misused educational subsidies for the same year would

39 Cf. a judgment of the Voivodeship Administrative Court in Poznań of 15 February 2018, III SA/Po 762/17, CBOSA. 
start differently in other local government units. It would be unacceptable in a democratic state of law. Anyway, it is difficult to link the subsidy settlement institution referred to in Article 38(1) of the AFET to the arising of the obligation to refund the subsidy mentioned in Article 252(1) of the PFA. If such iunctim was to take place, the legislator should anticipate this fact clearly on the basis of the AFET.

According to another perspective, the beginning of the limitation period for the obligation to return subsidies received from the budget of a local government unit and misused (similarly, in the case of subsidies received unduly or in excess) starts at the end of the year in which the beneficiary received and was supposed to use the subsidy ${ }^{40}$. Consequently, the decision determining the amount of the liability should be made and served within five years of the end of the calendar year in which the subsidy was awarded and was supposed to be used for its intended purpose. Undoubtedly, from all the positions on the matter presented so far, this one is the most advantageous for authorities running non-public educational units. It is supported by the argument that there is an obligation to reimburse the misused education subsidy by virtue of the law. In addition, attention is drawn to Article 252(6) point 1 of the PFA which specifies that an interest on subsidies to be repaid to the budget of a local government unit is to be charged from the date on which the misused subsidies are transferred from the budget of the local government unit ${ }^{41}$. However,

40 Cf. a judgment of the Voivodeship Administrative Court in Bydgoszcz of 23 March 2016, I SA/Bd 104/16, CBOSA; a judgment of the Supreme Administrative Court of 5 September 2018, I GSK 2583/18, CBOSA; a judgment of the Voivodeship Administrative Court in Gliwice of 4 April 2019, I SA/Gl 1340/17, CBOSA.

41 A similar argument was used by the Supreme Administrative Court in a judgment of 13 June 2017 (II GSK 3644/15, CBOSA), in a case which concerned the repayment of funds intended for the implementation of programmes financed with European funds that had been misused (Article 207 of the PFA). At that time, it indicated that the limitation period should be strictly linked to the nature of the liability to be repaid. Therefore, if the granted financial resources are undue within the meaning of the Act, and the obligation to return the undue co-financing arises at the moment when the prerequisites provided for by the provisions of the law appear, the obligation to return the funds should be related to the date when the beneficiary receives them. It decided so, partly on the basis of Article 207(1) of the PFA in which the legislator requires the cal- 
this argument can also be called into question. Indeed, the interest for late payment pursuant to Article 53(1) of the TO is a consequence of tax arrears, i.e. the failure to pay the tax on time (Article 51(1) of the TO) ${ }^{42}$. The question is whether it is not too far-reaching to derive from the fragment of Article 252(1) point 1 of the PFA which provides for the obligation to return the subsidy "with interest in the amount specified as on tax arrears" in connection with Article 252(6) point 1 of the PFA that the legislator treats the subsidy to be returned as tax arrears from the date of its receipt. In my opinion, the obligation to return a subsidy arises only at the moment when the funds are spent for purposes other than those for which they were intended. This is when the period of 15 days for the repayment of the funds, provided for in Article 252(1) point 1 of the PFA, begins. Therefore, the period of limitation of the obligation to return the misused educational subsidy will begin as of the end of the year in which the beneficiary received the subsidy only for that part of it, in relation to which the 15-day period of return under Article 252(1) point 1 of the PFA expired in the same year as the year of receipt of the subsidy.

In the context of the above observations, the de lege ferenda postulate should be put forward for the legislator to clearly determine the starting point for the calculation of the limitation period for the obligation to return the misused educational subsidy. Appropriate application of the regulations of Section III of the TO in this respect causes many ambiguities described here. De lege lata advocating the last of the presented positions results not so much from an unconditional conviction of its validity as from the in dubio pro tributario principle and a greater number of justified objections that can be made against other presented concepts concerning the beginning of the limitation period.

culation of interest on the amount to be repaid from the date of the transfer of funds to the beneficiary, considering such funds as tax arrears.

42 Cf. L. Etel, Komentarz do art. 53 o.p. [in:] L. Etel (ed.), Ordynacja podatkowa. Komentarz, Legal Information System LEX 2017. 


\section{The return of the excess subsidy in the context of the subsidy amount update}

The changes in legal regulations concerning educational subsidies described so far, made over the last few years, have contributed to the removal of significant doubts as to the interpretation of the old legal status (see determining the form in which the amount of the subsidy is established or transferred, or deciding the admissibility of financing expenses related to the implementation of the tasks of the governing body with the use of the educational subsidy).

By way of an amendment to the SEA, which entered into force on 1 January 2017, Article 89c was added to this legal act, which in paragraph 2 defined the rules of procedure in the event that the updated total amount of the annual subsidy per pupil, student, or participant of classes was changed in relation to its previous calculations ${ }^{43}$. A similar regulation is currently contained in Article 43(4) of the AFET which provides that if the amount of the subsidy referred to in Articles 15 to 21, 25(1) to (4) and (8), 26(1), (2) and (8), 28 to 30, 31(1), 40 and 41 has changed, the amount of the subsequent parts of the subsidy transferred for the child covered by the early development assistance, the pupil, a ward, a participant in revalidation and educational classes, or a student in a vocational qualification course, respectively, shall, from the first day of the validity of the updated amount of the subsidy, be the difference between the amount of the subsidy referred to in Article 15-21, 25(1) to (4) and (8), 26(1), (2) and (8), 28 to 30,31(1), 40 and 41, respectively, as applicable on the first day of the implementation of the updated amount of the subsidy, and the amount of the part of the subsidy transferred for the child covered by the early development assistance, the pupil, a ward, a participant in revalidation and educational classes or a student in a vocational qualification course, respectively, from the beginning of the budget year to the day preceding the first day of the implementation of the updated amount of the subsidy.

43 See Article 1(77) of the Act of 23 June 2016 amending the Act on the Education System and certain other acts. 
On the other hand, a normative novelty is the solution provided for in Article 43(5) of the AFET. This provision stipulates that in the case of equalization of the amount of the subsidy referred to in Articles 15-21, 25(1) to (4) and (8), 26(1),(2) and (8), 28-30, 31(1), 40 and 41, in accordance with paragraph 4 , the arithmetic mean of the successive parts of the subsidy transferred for a child covered by an early development assistance, the pupil, a ward, a participant in revalidation and educational classes, or a student in a vocational qualification course, respectively, from the first day of the updated amount of the subsidy may increase by a maximum of $50 \%$ or decrease by a maximum of $25 \%$ of the arithmetic mean of the part of the subsidy transferred for a child covered by early development assistance, a pupil, a ward, participant in revalidation, and educational classes or a student in a vocational qualification course, respectively, from the beginning of the budget year to the day preceding the first day of the updated amount of the subsidy. Therefore, maximum thresholds were established for possible additional payments to a part of the subsidy in the case of an underpayment or for deductions in the case of overpayment. From the justification of the draft act introducing the legal construction described above, it follows that its ratio legis was to establish a security against such a significant drop in the amount of subsidy after the update, as could cause difficulties in financing school tasks by the governing body ${ }^{44}$. It should be deduced from the annual character of the educational subsidy that no deductions can be made from the subsidy granted for the subsequent financial year for the subsidy overpaid in the previous year. Thus, deductions may be made only in respect of a successive subsidy instalments for the same year.

The regulation analysed in this paper has not been discussed so far in the literature on the subject, where numerous questions are posed in its context, not necessarily combined with answers ${ }^{45}$. One can hardly fail to

44 Government bill on financing educational tasks with draft executive acts, Sejm paper No 1837, Sejm of the 8th term, http://orka.sejm.gov.pl/Druki8ka.nsf/0/7DCEF5F10388F338C12581A2003F01ED/\%2 4File/1837.pdf, (access on-line: 19 September 2019).

45 Cf. A. Pawlikowska, W. Lachiewicz, Ustalenie wysokości dotacji oświatowej [in:] W. Lachiewicz, A. Pawlikowska (ed.), Dotacje oświatowe..., p. 74. 
notice that the content of Article 43(5) of the AFET may be a significant problem for administrative courts in cases concerning the payment of subsidies up to the full amount or the reimbursement of overpaid subsidies. Focusing only on the latter, it can already be observed that administrative bodies issue decisions pursuant to Article 252(1) point 2 of the PFA when, despite the deductions made within the limits set out in Article 43(5) of the AFET, at the end of a financial year the amount of the subsidy paid to a non-public educational unit is higher than the amount of subsidy due - assuming that this is a case of an overpayment. Is such a procedure correct?

At the outset, it should be noted that in accordance with Article 252(3) of the PFA, the subsidies received in excessive amounts are the ones received from the budget of a local government unit in an amount higher than specified in separate regulations, or in a contract, or represent an amount higher than necessary to co-finance or finance a subsidized task. However, pursuant to Article 253 of the PFA, the provisions of Article 251 and Article 252 of the PFA shall not apply if separate acts specify the rules and mode of subsidy reimbursement. The question is, therefore, whether Article 43(5) of the AFET, which would exclude the application of the instrumentality under Article 252(1) point 2 of the PFA, i.e. recognising the part of the overpaid subsidy which was not deducted owing to the legally defined limit as the subsidy received in the excessive amount, will not be a separate provision in this case. Such an assumption would mean that the part of the overpaid subsidy which could not be "recovered" by the local government units by way of deductions is forfeited and that the obligation to return it does not exist on the part of the body running the non-public educational unit. In my opinion, this type of an interpretation of the aforementioned provisions is unacceptable, as it leads to a clear violation of the interest of individual local government units, i.e. of the general public interest. Article 43(5) of AFET does not define exhaustively the procedure and the mode of the reimbursement of the excessive amount of the educational subsidy, but refers only to the maximum amount of overpayment deductions from the part of the subsidy remaining to be paid in a given calendar year. Nor was this the intention of the legis- 
lator, who established the standard in question. Therefore, I do not see any grounds for applying Article 253 of the PFA and excluding the application of Article 252(1) point 2 of the PFA in this case. However, it cannot be ruled out that the approach of administrative courts to this problem will be different, which should provide a basis for the introduction of legal solutions clearly determining the consequences of the provisions of Article 43(5) of the AFET.

\section{Procedural problems}

Pursuant to Article 67 of the PFA, the provisions of the Act of 14 June 1960, Code of Administrative Procedure (hereinafter referred to as the CAP $)^{46}$ are applicable to non-taxable budget receivables of a publicprivate nature, including educational subsidies. Pursuant to Article 61(1)(4) of the PFA, the bodies of first instance competent to issue decisions with regard to the reimbursement of educational subsidies to the budgets of local government units are the head of the commune (voit), the mayor or the president of the city. The appeal bodies, in turn, are to be the locally competent local government appeal boards. As in any similar case, also in the case of educational subsidies, crucial importance should be attached to the correct determination of the subjective and the objective scope of administrative proceedings.

The incorrect definition of the catalogue of parties to proceedings has far-reaching consequences. On the one hand, in a case concluded with a final decision, proceedings are resumed if the party failed to participate in the proceedings through no fault of its own (Article 145(1) point 4 of the CAP). On the other hand, a public administration body invalidates a decision if that body addresses it to a person who is not a party to the proceedings (Article 156(1) point 4 of the CPA). Pursuant to Article 28 of the CAP, a party is any person whose legal interest or obligation is affected by the proceedings or who requests the authority to act on the basis of its legal interest or obligation. As stipulated in Article 29 of the CAP the

46 Consolidated text: Dz.U. of 2018, poz. 2096 with subsequent amendments. 
parties may be natural and legal persons, and in the case of state and local government organisational units and social organisations - also units without legal personality. A special category of parties to administrative proceedings are the so-called imperfect legal persons (with limited legal capacity), i.e. organisational units which are not legal persons that are granted legal capacity by the Act. The basis for their capacity is considered by administrative courts in Article $33^{1}$ (1) of the Act of 23 April 1964 - The Civil Code (hereinafter referred to as the CC) ${ }^{47}$, which requires the application of the provisions on legal persons to these entities ${ }^{48}$.

Educational subsidies are granted to kindergartens, other forms of pre-school education, schools, and institutions. Those of the aforementioned entities which are non-public units, in accordance with Article 8(2) points 2 and 3, and Article 8(3) of the EL, may be established and run by legal persons other than local government units or by natural persons. It is unclear whether there is a possibility for the performance of the function of a governing body by the so-called imperfect legal persons (with limited legal capacity), also owing to their exclusively economic character resulting from Article 8(2) of the Act of 15 September 2000 - Commercial Companies Code $^{49}$. Non-public educational units do not have legal personality, they are neither natural persons, nor legal persons, nor so-called imperfect legal persons (with a limited legal capacity). Their financial management is the responsibility of their governing bodies, which may be derived from Article 10(1) of the EL. As a consequence, the entity obliged to return the educational subsidy in the cases referred to in Article 251(1) and Article 252(1) of the PFA is the body running a kindergarten, another form of pre-school education, a school, or an institution. Administrative proceedings to determine the amount of subsidy to be reimbursed should be initiated against the governing body, which shall have the status of a party in such proceedings. At the same time, there is no obstacle to de-

\footnotetext{
Consolidated text: Dz.U. of 2019, poz. 1145.

48 Cf. e.g. a judgment of the Voivodeship Administrative Court in Warsaw of 11 March 2004, II SA 1563/03, CBOSA.

49 Consolidated text: Dz.U. of 2019, poz. 505 with subsequent amendments. More on the subject, cf. M. Pilich, Komentarz do art. 8 [in:] M. Pilich (ed.), Prawo oświatowe oraz przepisy prowadzajqce. Komentarz, Warszawa 2018, p. 64.
} 
termine in one procedure, concluded with a single decision, the amount of subsidies to be reimbursed, which have been granted to various nonpublic educational units - provided that the body governing these units is identified ${ }^{50}$.

In the context of determining the scope of the subjective administrative proceedings, it is necessary to refer to the situation in which the governing bodies of a given non-public educational unit are entities operating within the framework of a civil partnership. Since a civil law partnership cannot be the governing body (a contrario to Article 8(2) point 2 and 3 of the EL), it cannot be a party to a legal and financial relationship concerning educational subsidies. The inability to become a party to the legal relationship resulting from the substantive law will ultimately determine that the civil law partnership cannot be a party to administrative proceedings to determine the amount of the subsidy to be reimbursed ${ }^{51}$. The parties will be the individual partners of such a company.

It is worth considering at this point the scope of responsibility of each partner of the civil partnership for the obligation to return the educational subsidy. In practice, the activities of public administration bodies can be met with various solutions in this respect. The first one assumes that the partners are not jointly and severally liable for the obligation. The scope of liability of individual shareholders may differ, since it results from their respective shares in the company. It is a concept difficult to defend for purely practical reasons, since participation in a civil partnership may be understood as a membership in that partnership, but also the possession of all rights, obligations and responsibilities resulting from that membership $^{52}$. Moreover, Article 863(1) of the CC mentions the participation of a partner in the joint property of partners, and Article 867(1) of the CC

50 Cf. a judgment of the Voivodeship Administrative Court in Wrocław of 30 January 2015, III SA/Wr 717/14, CBOSA.

51 A contrario to the remarks included in a judgment of the Supreme Administrative Court of 22 August 2000. V SA 2021/99, CBOSA. Cf. also a judgment of the Supreme Administrative Court of 9 February 1995, V SA 418/94, CBOSA.

52 Cf. A. Kidyba, K. Kopaczyńska-Pieczniak, Komentarz do art. 860 [in:] A. Kidyba (ed.), Kodeks cywilny. Komentarz. Tom III. Zobowiqzzania - część szczególna, wyd. II, Legal Information System LEX 2014. 
mentions the participation in profits and losses. Therefore, it remains unclear which of these shares should be used as the basis for determining the scope of responsibility of each partner for the liability we are interested in. According to the second position, the liability of civil partnership partners is joint and several. Article 65 of the PFA requires the application of the provisions of the $\mathrm{CC}$ to joint and several liability for liabilities arising from non-taxable budget receivables of a public-law nature. Also, the appropriately applied Article 91 of the TO indicates the necessity to apply the CC provisions concerning civil law liabilities to joint and several liability for tax liabilities. For some authors, it is enough to derive joint and several liability of civil partnership partners running a kindergarten or a school from the content of these two regulations ${ }^{53}$. This does not appear to be correct, since none of these provisions presupposes the joint and several liability for the obligation to reimburse the subsidy. Solidarity, on the other hand, must not be presumed. In judicial decisions, it is added that the source of the solidarity of partners in a civil partnership is a legal act - incurring a public-law obligation to use public funds received under an educational subsidy for a given unit in accordance with their intended use. The legal basis for their solidarity is considered to be Article 370 of the $\mathrm{CC}$, which states that if several persons have assumed an obligation concerning their common property, they are jointly and severally liable, unless otherwise agreed ${ }^{54}$. It is difficult to defend this position if it is undisputed that the payment of the subsidy is an activity within the scope of public administration, which is provided for in Article 3(2) point 4 of the LPAC. The sources of joint and several liability of civil partnership partners for the obligation to return the educational subsidy should, in my opinion, be found rather in Article 864 of the CC, which is a general basis for the joint and several liability of partners for the liabilities of the partnership (in fact, not so much for the liabilities of the partnership, but

53 Cf. A. Pawlikowska, W. Lachiewicz, Dochodzenie zwrotu dotacji od beneficjenta [in:] W. Lachiewicz, A. Pawlikowska (ed.), Dotacje oświatowe..., p. 249.

54 Cf. a judgment of the Voivodeship Administrative Court in Lublin of 29 April 2015, I SA/Lu 232/15, CBOSA; a judgment of the Voivodeship Administrative Court in Lublin of 23 March 2016, I SA/Lu 1078/15, CBOSA. 
simply for the common liabilities of the partners) and refers also to publiclaw liabilities ${ }^{55}$.

When determining the scope of the parties to the administrative proceedings to determine the amount of the subsidy to be returned, it is also necessary to mention the content of Article 112(1) of the TO. This provision provides that the purchaser of an enterprise or an organised part of an enterprise is jointly and severally liable with the taxpayer for tax arrears related to the conducted business activity, which arose up to the date of acquisition, unless he or she could not with due diligence have known about those arrears. Does this provision apply in a situation where a different entity was the governing body at the time when the tax arrears arose and yet another one was the governing body at the time when the amount of the subsidy to be returned was determined (a change in the governing body will occur)? The answer to this question is negative owing to the content of Article 170 of the EL (previously Article 83a of the SEA). According to its wording, running a school or an institution, or a team referred to in Article 182, and/or another form of a pre-school education is not an economic activity. The content of the provision leaves no doubt that the activity conducted in the form of a kindergarten, another form of a pre-school education, an institution, a group of schools or non-public institutions, is not an economic activity, even if it meets the conditions for being recognised as such in the light of Article 3 of the Act of 6 March 2018 - Entrepreneurial law ${ }^{56}$. Thus, a non-public educational unit cannot be considered an enterprise in the material sense, as provided for in Article $55^{1}$ of the CC, even if the governing body is an entrepreneur by virtue of conducting activities other than educational ones. This is a paradoxical situation as the jurisprudence of administrative courts points to an economic goal in the form of generating profit, which is the goal of many

55 Cf. P. Pinior, Komentarz do art. 864 [in:] M. Fras, M. Habdas (eds.), Kodeks cywilny. Komentarz. Zobowiq̨zania. Tom V. Część szczególna, Legal Information System LEX 2018.

56 Consolidated text: Dz.U. of 2019, poz. 1292 with subsequent amendments. Cf. M. Pilich, Komentarz do art. 170 [in:] M. Pilich (ed.), Prawo oświatowe oraz przepisy prowadzajqce. Komentarz, Warszawa 2018, p. 733. 
private entities running a school or institution ${ }^{57}$. Sometimes they are called directly "entrepreneurs" 58 . Therefore, we are faced with yet another example of a situation requiring the intervention of the legislator.

When determining the subject matter of administrative proceedings in the notice of its initiation under Article 61(4) of the CAP, it should first of all be noted that the obligation to return the educational subsidy arises by a virtue of the law, and the decision issued in this respect is declaratory in nature. The subject of the proceedings will therefore be to "determine", for the body governing a given educational unit, the amount of the subsidy to be returned to the budget of the relevant local government unit. Such a term should also be used in the decision terminating the proceedings. Of course, here it is assumed that any part of the subsidy is deemed eligible for reimbursement. One should also remember that Article 251(1) and Article 252(1) of the PFA list four different cases in which the obligation to return the subsidy arises. These are: 1 . unused subsidies at the end of the financial year; 2. misused subsidies; 3. undue receipt of subsidies; 4. excessive receipt of subsidies. This must be taken into account when determining the subject matter of the procedure and when formulating the operative part of the decision, so as not to expose oneself to the risk of being accused of exceeding the subject matter of the procedure.

In conclusion to the procedural remarks, it is worth referring to the question of evidence. Taking into account the content of Article 7 and Article 77(1) of the CAP, the body conducting the proceedings is obliged to prove with the help of evidence gathered in the case that a specific amount of the subsidy is to be returned to the budget of a competent local government unit for the reason specified in the PFA regulations. (formerly Article 90(3e) and $n$ of the SEA). Conducting such an inspection is not a prerequisite for initiating and concluding administrative proceedings to determine the amount of subsidy to be reimbursed. However, experience shows that without such an inspection it is not easy to issue a decision

57 Cf. a judgment of the Voivodeship Administrative Court in Bydgoszcz of 22 May 2018, I SA/Bd 194/18, CBOSA. Cf. also J. Pierzchała, Prawo oświaty..., p. 179.

58 Cf. a judgment of the Supreme Administrative Court of 6 December 2016, II GSK 1380/15, CBOSA. 
which will "defend itself" in the course of an administrative court inspection. This is particularly true as the administrative courts require the investigating authorities to determine and justify accurately and precisely in their decision why a given part of the subsidy is subject to the reimbursement obligation. Let the problem be illustrated by one of the judgments ordering the body conducting the proceedings to determine what part of the vehicle mileage performed four years earlier in relation to the date of the judgement was related to the performance of the tasks of a kindergarten in the area of education, upbringing and care, including social prevention. The educational subsidy was used to finance expenditure on the payment of leasing installments for a car and it was necessary to calculate the proportion in which the vehicle was used in connection with the performance of the aforementioned tasks in relation to its total mileage, and then determine the amount of the subsidy that was used for purposes other than those for which it was intended ${ }^{59}$.

The obligations mentioned above should also apply directly to the part of the decision in which the authority decides to determine the amount of subsidy to be returned together with the interest at the rate specified as on tax arrears. The regulations concerning the determination of the initial date from which interest is due are regulated in Article 251(5) and Article 252(6) of the PFA. What seems particularly interesting is the case of the educational subsidy misuse. In this case the interest on the subsidy to be returned is calculated starting from the date when the misused subsidies were transferred from the budget of the local government unit (Article 252(6) point 1 of the PFA). Subsidies are transferred in 12 installments paid within the prescribed time limits (Article 34(1) of the AFET). Thus, the body conducting the proceedings should make an attempt to determine from which part of the subsidy a given expense, the legality of which is questioned, was made. It is possible to imagine that an expense made e.g. in April of a given year was covered by funds paid for another, earlier month. Only as a result of the ineffectiveness of such find-

59 Cf. a judgment of the Voivodeship Administrative Court in Bydgoszcz of 12 October 2016, I SA/Bd 537/16, CBOSA. 
ings can we assume that the expenditure is allocated to a specific part of the subsidy on the basis of the date on which it was made ${ }^{60}$.

\section{Conclusions}

The identification and discussion of legal problems related to the recovery of subsidies to non-public educational units contained in this article is not exhaustive. It shows, however, that we are dealing with a multi-threaded issue requiring simultaneous (and often "appropriate”) application of regulations from several different legal acts. This must cause numerous difficulties both for the bodies running non-public educational units and for the administrative authorities competent to determine the amount of subsidies to be returned. At the same time, the unstable and inconsistent jurisprudence of administrative courts does not help the situation.

Owing to the fact that educational subsidies are public funds from the budgets of local government units, the principles of their allocation and disbursement should be regulated by the law as clearly and as accurately as possible. Appreciating the positive impact of legislative changes made in this area over the years, it is necessary to make a few de lege ferenda postulates.

First of all, the legislator should determine the nature of funds paid to non-public educational units by virtue of the judgments of common courts, adjudged on account of unreceived subsidies or parts thereof. If these funds should be treated as subsidies, it is necessary to establish the rules of their settlement and disbursement. Secondly, when amending legal acts in the area we are interested in, one should pay attention to the justifications for the relevant draft amendments, since the experience of administrative courts shows that they sometimes give a very high priority

60 Acceptance of such a mode of operation, cf. a judgment of the Voivodeship Administrative Court in Bydgoszcz of 23 August 2016, I SA/Bd 304/16, CBOSA; a judgment of the Voivodeship Administrative Court in Bydgoszcz of 4 October 2016, I SA/Bd 412/16, CBOSA; a judgment of the Voivodeship Administrative Court in Bydgoszcz of 29 August 2017, I SA/Bd 714/17, CBOSA; a judgment of the Voivodeship Administrative Court in Bydgoszcz of 22 May 2018, I SA/Bd 194/18, CBOSA. 
to the formulations contained therein. If the will of the legislator is to provide some solutions with retroactive effect, it should be clearly stated in the legal act itself. Thirdly, there is a need to clarify when the limitation period for the obligation to return educational subsidies misused should commence. Fourthly, there is a need to clarify whether the statutory limits on the deduction of overpaid educational subsidies preclude the possibility of claiming the remainder of the deduction as having been overcharged. Fifthly and finally, it seems justified to remove the exclusion of nonpublic entities of the education system from the group of business activities. Such a solution will make it possible to apply Article 112(1) of the TO in cases concerning the determination of the amount of subsidy to be returned to the budget of the relevant local government unit. At the same time, it broadens the scope of responsibility for the arrears and increases the chance of their recovery by the local government unit.

\section{Bibliography:}

Czarnecki K., Dotacje budżetowe. Konstrukcja prawna i procedury, TNOiK, Toruń 2018.

Domagalski M., Gdzie iść ze sporem o dotacje oświatowe, „Rzeczpospolita” magazine, issue: 4 July 2019, No 11397, p. A14.

Etel L., Komentarz do art. 53 o.p. [in:] L. Etel (ed.), Ordynacja podatkowa. Komentarz, Wolters Kluwer, Legal Information System LEX 2017.

Gajewski S., Sq̨dowoadministracyjna kontrola udzielania dotacji z budżetów jednostek samorzqdu terytorialnego, o których mowa w art. 90 ustawy z 7.09.1991 r. o systemie oświaty, „Finanse Komunalne” 2015, No 4, pp. 52-59.

Kidyba A., Kopaczyńska-Pieczniak K., Komentarz do art. 860 [in:] A. Kidyba (ed.), Kodeks cywilny. Komentarz. Tom III. Zobowiqzania - część szczególna, wyd. II, Legal Information System LEX 2014, Wolters Kluwer.

Kokot J., Komentarz do art. 90 u.s.o. [in:] A. Balicki, M. Pyter, J. Kokot (ed.), Ustawa o systemie oświaty. Komentarz, wyd. I, System Informacji Prawnej, C.H. Beck, Legalis 2016.

Lachiewicz W., Pawlikowska A., Dotacje oświatowe, C.H. Beck, Warszawa 2019. Morawski L., Zasady wykładni prawa, TNOiK, Toruń 2010. 
Olszewski A., Konsekwencje intertemporalne zmiany przepisów regulujących kwestie dotowania przedszkoli, szkół oraz placówek prowadzonych przez podmioty inne niż jednostka samorzqdu terytorialnego $w$ zakresie dopuszczalności drogi sqqdowej, „Finanse Komunalne” 2018, No 4, pp. 5-13.

Ostrowska A., Spór o właściwość sq̨dowq w sprawach ustalania wysokości dotacji oświatowych, „Finanse Komunalne” 2015, No 3, pp. 6-16.

Pierzchała J., Prawo oświaty prywatnej, Wolters Kluwer, Warszawa 2016.

Pilich M., Komentarz do art. 8 i art. 170 [in:] M. Pilich (ed.), Prawo oświatowe oraz przepisy prowadzajq̨ce. Komentarz, Wolters Kluwer, Warszawa 2018.

Pilich M., Komentarz do art. 90 u.s.o. [in:] M. Pilich (ed.), Ustawa o systemie oświaty. Komentarz, wyd. VI, Legal Information System LEX 2015, Wolters Kluwer.

Pinior P., Komentarz do art. 864, [in:] M. Fras, M. Habdas (red.), Kodeks cywilny. Komentarz. Zobowiqzzania. Tom V. Część szczególna, Wolters Kluwer, Legal Information System LEX 2018.

Stawiński M., Komentarz do art. 252 u.f.p. [in:] Z. Ofiarski (ed.), Ustawa o finansach publicznych. Komentarz, System Informacji Prawnej LEX 2019, Wolters Kluwer.

Szalewska M., Zwrot dotacji przez przedszkola niepubliczne [in:] A. Borodo (ed.), Dotacje i subwencje $w$ systemie finansowym samorzqdu terytorialnego, TNOiK, Toruń 2013.

Szymańska A., Podleśna-Porczak M., Kułakowska K., Udzielanie dotacji z budżetów jednostek samorzqdu terytorialnego jednostkom oświatowym - dylematy prawne w świetle ustaleń kontroli regionalnych izb obrachunkowych, „Finanse Komunalne” 2014, No 10, pp. 48-63.

Świątek P., Wykorzystanie dotacji udzielonych z budżetu jednostek samorzqdu terytorialnego dla niepublicznych jednostek systemu oświaty w świetle orzecznictwa sq̨dów administracyjnych, „Finanse Komunalne” 2017, No 7-8, pp. 49-58. 